\title{
Renaissance of laser interstitial thermal ablation
}

\author{
Symeon Missios, MD, ${ }^{1}$ Kimon Bekelis, MD, ${ }^{2}$ and Gene H. Barnett, MD, MBA ${ }^{3}$ \\ 1Department of Neurosurgery, Louisiana State University Health Sciences, Shreveport, Louisiana; ${ }^{S}$ Section of Neurosurgery, \\ Dartmouth-Hitchcock Medical Center, Lebanon, New Hampshire; ${ }^{3}$ The Rose Ella Burkhardt Brain Tumor \& Neuro-Oncology \\ Center, Department of Neurosurgery, Cleveland Clinic Foundation, Cleveland, Ohio
}

\begin{abstract}
Laser interstitial thermal therapy (LITT) is a minimally invasive technique for treating intracranial tumors, originally introduced in 1983. Its use in neurosurgical procedures was historically limited by early technical difficulties related to the monitoring and control of the extent of thermal damage. The development of magnetic resonance thermography and its application to LITT have allowed for real-time thermal imaging and feedback control during laser energy delivery, allowing for precise and accurate provision of tissue hyperthermia. Improvements in laser probe design, surgical stereotactic targeting hardware, and computer monitoring software have accelerated acceptance and clinical utilization of LITT as a neurosurgical treatment alternative. Current commercially available LITT systems have been used for the treatment of neurosurgical soft-tissue lesions, including difficult to access brain tumors, malignant gliomas, and radiosurgery-resistant metastases, as well as for the ablation of such lesions as epileptogenic foci and radiation necrosis. In this review, the authors aim to critically analyze the literature to describe the advent of LITT as a neurosurgical, laser excision tool, including its development, use, indications, and efficacy as it relates to neurosurgical applications.
\end{abstract}

http://thejns.org/doi/abs/10.3171/2014.12.FOCUS14762

KEY WORDS laser interstitial thermal therapy; laser ablation; oncology

$\mathrm{L}$ ASER interstitial thermal therapy (LITT) is a minimally invasive technique for treating intracranial tumors percutaneously. The concept has existed since the late 1970s, and in 1983 Bown and colleagues ${ }^{6}$ used a neodymium-doped yttrium aluminum garnet (Nd:YAG) laser and achieved focal tissue coagulation in an experimental brain tumor model without tissue vaporization. Several experimental animal models were developed and further demonstrated the brain tissue changes in response to hyperthermia. ${ }^{11,12,17,53,54}$ However, the lack of accurate control and the inability to monitor the laser-induced thermal effects limited the widespread application of this therapy. The development of magnetic resonance (MR) thermography, ${ }^{14}$ based on the temperature dependence of the proton resonance frequency, allowed realtime image guidance of laser thermal energy delivery and rendered the treatment of deep, otherwise inaccessible lesions feasible.

Current commercially available LITT systems have been used for the treatment of neurosurgical lesions, including difficult-to-access malignant gliomas ${ }^{45,46}$ and radiosurgeryresistant metastases,, 20 as well as the ablation of lesions such as epileptogenic foci ${ }^{55}$ and radiation necrosis. ${ }^{23,39}$ In this review, we aim to critically analyze the literature to describe the advent of LITT as a neurosurgical, laser excision tool, including its development, use, indications, and efficacy as it relates to neurosurgical applications.

\section{Biological Effects of Laser Therapy}

Laser electromagnetic radiation (EMR) has been the most frequently used source of illumination in the treatment of cancer. In tumors it relies on the principle of using high-intensity EMR to treat tumors and incorporates a number of variables such as wavelength, power density, duration of exposure, and method of exposure, such as surface versus interstitial irradiation. ${ }^{17}$ Initially, the application of laser therapy was confined to surface regions, such as the skin or the digestive tract lumen, due to sole reliance on visual control for monitoring. ${ }^{26}$ Interstitial laser irradiation allows the delivery of laser energy directly into the tumor tissue, maximizing its penetration and effectiveness, while minimizing its destructive effects on surrounding normal tissues. ${ }^{17}$ It had been known that the

ABBREVIATIONS EMR = electromagnetic radiation; GBM = glioblastoma multiforme; LITT = laser interstitial thermal therapy; Nd:YAG = neodymium-doped yttrium aluminum garnet; OS = overall survival; PFS = progression-free survival; PRF = proton resonance frequency; TDT = thermal-damage-threshold.

SUBMITTED November 3, 2014. ACCEPTED December 15, 2014

INCLUDE WHEN CITING DOI: 10.3171/2014.12.FOCUS14762.

DISCLOSURE Dr. Barnett is a consultant for and owns stock in Monteris Medical, Inc. 
thermal effects of EMR were confined to the region where the optical energy was absorbed,${ }^{50}$ but the lack of an effective, real-time monitoring system limited the application of laser therapy, especially in deep locations.

The major biological effect of laser interstitial irradiation is thermal damage. ${ }^{47}$ At the interface of laser radiation and biological tissue, laser light photons are absorbed by surrounding tissue molecules, causing excitation and release of thermal energy. After EMR energy is converted to heat, redistribution of heat takes place through convection and conduction via blood flow. Heat redistribution is not a uniform process and relies on the applied laser power and the properties of the surrounding tissues. ${ }^{26}$ Laser EMR with wavelength in the near-infrared part of the spectrum has the greatest degree of tissue penetration, on the order of $2-10 \mathrm{~mm} .{ }^{33}$ The properties that characterize the distribution of laser light in tissues are absorption, scattering, and bending. Absorption is mainly determined by water and hemoglobin content. ${ }^{33}$

LITT results in heating the treated tissue and causing enzyme induction, protein denaturation, melting of membrane lipids, vessel sclerosis, and coagulation necrosis. Heat-induced tissue necrosis results from a temperature increase above $43^{\circ} \mathrm{C}$, with the time until cell death depending exponentially on temperature. ${ }^{33}$ Rapid increases in temperature can cause tissue carbonization, which subsequently changes the tissue optical properties and limits laser penetration. ${ }^{37}$ Overheating can also lead to tissue vaporization, which if not released, could lead to an increase in intracranial pressure. ${ }^{38}$

The optical properties of the target tissue also affect laser thermal delivery. Yaroslavsky and colleagues ${ }^{56}$ analyzed the optical properties of selected native and coagulated human brain structures in the spectral range between 360 and $1100 \mathrm{~nm}$. The absorption coefficients, the scattering coefficients, and the anisotropy factors of the samples were determined, and analysis revealed that thermal coagulation reduced the optical penetration depth substantially. The highest penetration depths for all tissues investigated were found in the wavelength range between 1000 and $1100 \mathrm{~nm}$, in the near-infrared part of the spectrum. Svaasand and Ellingsen ${ }^{51}$ reported measurements of the optical properties of human brain tissue and demonstrated heterogeneity and age-dependent differences in optical penetration depth. The following year, Svaasand ${ }^{49}$ published an analytical dosimetry model for laser-induced hyperthermia used for an in vivo murine mammary adenocarcinoma strain. The author concluded that the depth of thermal necrosis was a function of optical wavelength, power density, exposure time, and cooling conditions. Eggert and Blazek ${ }^{16}$ evaluated the optical properties of meninges, normal human brain tissue, and brain tumors at the spectral range between 200 and $900 \mathrm{~nm}$. Within the visible and near-infrared spectral range, white matter showed the lowest level of absorption and the shortest penetration depth, low-grade gliomas revealed optical properties similar to those of gray matter, and meningiomas and glioblastomas showed significantly higher levels of absorption. The goal of LITT is to achieve selective thermal injury of pathological tissue while maintaining a sharp thermal border between the normal and tumor tissues.

\section{Types of Lasers Used for LITT}

The two main types of lasers used for LITT are the continuous-wave Nd:YAG, with a wavelength of $1064 \mathrm{~nm}$ and diode lasers with wavelengths between 800 and 980 $\mathrm{nm}$ that operate at a wide range of powers. ${ }^{37,38,45} \mathrm{Nd}$ :YAG lasers achieve the highest degree of tissue penetration at wavelengths between 1000 and $1100 \mathrm{~nm}$, within the nearinfrared spectrum where scattering of light is greater than its absorption, thus resulting in greater tissue penetration. ${ }^{37,47}$ They are indicated for use in soft tissues with high blood perfusion, ${ }^{37}$ such as brain tissue that is highly vascularized and perfused. Diode lasers have a higher water absorption coefficient than does the Nd:YAG laser and are thus capable of producing lesions in less time. The combination of rapid energy deposition and high optical absorption allows for sharp thermal gradients at the boundary of the ablation zone. ${ }^{9}$

\section{LITT Probes}

Laser thermal ablation is introduced into the tumor via an optical fiber, typically of a $600-\mu \mathrm{m}$ diameter of which the terminal approximately $1 \mathrm{~cm}$ is exposed. ${ }^{37}$ Such fibers can be damaged if they absorb part of the laser energy they conduct and thus are made of heat-resistant, flexible material that typically do not absorb light between 200 and $2000 \mathrm{~nm}$. Quartz or sapphire optical fibers have been used and allow the transmission of laser energy with practically no loss. Initial LITT treatments used a bare tip probe design that resulted in overheating, tissue carbonization, and subsequent diminished thermal penetration and often times optical fiber damage..$^{47}$ Subsequent developments in probe design introduced enclosure of the optical fiber in a diffusion sheath, which allowed for the power density to be reduced across the tip and for a higher laser power to be used; it also offered a nonstick surface lining the exposed optical fiber. ${ }^{7,37}$

One of the most important advances in LITT probe design was the introduction of a cooling mechanism that takes the form of a sheath-like device that cools the optical fiber with a constant stream of fluid (water or saline) or cooled gas (liquid $\mathrm{CO}_{2}$ ). The cooling mechanism removes heat from the probe-tissue interface and minimizes carbonization or vaporization and allows for creation of larger treated volumes. ${ }^{1,38}$ The cooled probe surface further minimizes probe adherence to treated tissues and decreases the incidence of probe failure.

The pattern of thermal energy deposition at the probe tip typically resembles a uniform ellipsoid lesion along the axis of the fiber. Advances in probe design led to the development of side-firing laser probes, allowing for asymmetrical tissue penetration. Cooling of the laser probe tip further accentuates the directionality of such side-firing probes. This control of the directionality of thermal energy deposition allows for "sculpting" of the laser thermal effect and conformal laser thermal coagulation of asymmetrical tumors.

\section{Histological Changes Induced by LITT}

Heat creates tissue necrosis via both acute and chronic 
effects that include edema, neuronal swelling, and cell membrane disruption. ${ }^{43}$ Heat-induced tissue necrosis results from temperature increase above $43^{\circ} \mathrm{C} .{ }^{33}$ The combination of tissue necrosis and edema may result in an increase in the volume of the treated lesion. ${ }^{45}$ The edema is resorbed and after approximately 1 week posttreatment, granulation tissue forms, which may be followed by development of cystic changes and a gliotic margin surrounding unresorbed necrotic tissue. ${ }^{37}$

Norred and Johnson ${ }^{37}$ have described 3 tissue regions surrounding the laser probe after interstitial thermal therapy that can be seen on MRI and correspond to distinct histological appearances and findings. The first zone is closest to the laser probe tip and represents the area of greatest energy absorption and tissue destruction. At temperatures of $50^{\circ} \mathrm{C}-100^{\circ} \mathrm{C}$, the tissues surrounding the probe tip undergo coagulation necrosis. Carbonization and vaporization occur typically at temperatures greater than $100^{\circ} \mathrm{C}$, and the resulting carbonized tissues exhibit increased energy absorption, which limits the penetration of the thermal delivery. The second zone is an intermediate region with necrotic tissue and increased interstitial fluid, and the third zone is a marginal zone comprising injured but viable cells. Tissue necrosis occurs at the zone closest to the probe tip and the intermediate zone.

\section{MR Thermometry}

Several investigators examined the thermal effects of interstitial laser thermal effects by measuring changes in temperatures in vivo by several techniques, including infrared detectors, ${ }^{4}$ thermometers, ${ }^{12,25}$ thermistors placed over the skin $^{15}$ or interstitial thermistor probes, ${ }^{17}$ subcutaneous thermocouple probes, ${ }^{22}$ and thermographic cameras. ${ }^{31}$ Real-time image guidance was explored as a means of monitoring treatment delivery and ensuring safety, and MRI was investigated as a potential imaging modality because of its soft-tissue contrast, sensitivity to temperature, and ability to visualize thermal lesions. ${ }^{11}$ The goal remained to develop an MRI sequence that would allow the visualization and quantification of the deposition of heat energy in the treated and surrounding tissue while providing adequate spatial and temporal resolution.

Standard T2-weighted MRI sequences accurately demonstrate thermal lesions after treatment but cannot be used for real-time monitoring because of a time delay of more than 15 minutes before the lesion appears. ${ }^{10}$ Magnetic resonance thermography based on the temperature-dependent water proton resonance frequency (PRF) was investigated for temperature monitoring of interstitial thermal therapy. De Poorter ${ }^{14}$ reported on the excellent linearity and temperature dependence of the PRF and its ability to detect temperatures well without being hindered by the different tissue types. Since then, PRF-based phase mapping methods have formed the basis of MR thermometry and have been the preferred noninvasive temperature monitoring sequence for many in vivo applications. ${ }^{41}$ The concept of PRF-based phase mapping relies on the fact that hydrogen nuclei (protons) are screened more efficiently from the magnetic field when in a free $\mathrm{H}_{2} \mathrm{O}$ molecule than in an $\mathrm{H}_{2} \mathrm{O}$ molecule that is hydrogen-bonded to another. As temperature increases, the number of hydrogen bonds decreases and thus the susceptibility of the medium changes, leading to a lower magnetic field and lower PRF.41

The ability to accurately visualize temperature changes using MR thermometry allowed the development of MR thermometry-based feedback control of LITT using a computer workstation and appropriate software. McNichols and colleagues ${ }^{32}$ reported on the use of such an integrated feedback-controlled system used on an animal model, including brain lesioning. Their lesions were correlated with histological findings, and they reported accurate MR thermometry estimation of thermal necrosis and no carbonization, vaporization, or applicator damage under feedback control.

\section{Radiographic Appearance of LITT-Treated Lesions}

Magnetic resonance imaging within the first 3 months after LITT reveals a distinct pattern of 3 zones that correspond to the histological zones of tissue injury. The probe tract can be seen, especially on T2-weighted images, and a decrease in the contrast enhancement of the lesion is typically seen on T1-weighted images. ${ }^{38} \mathrm{~A}$ central zone is seen surrounding the probe tract, hypointense on T1-weighted images and hyperintense on T2-weighted images. Surrounding the central zone, a peripheral zone is seen that is surrounded by a contrast-enhancing margin, which confers a distinct "eggshell"-like appearance to the lesion. Beyond the peripheral zone, a margin dose of edema is seen, hypointense on T1-weighted and hyperintense on T2-weighted images. The lesion typically enlarges to approximately 1.5 times its original size and can remain enlarged for up to 40 days due to the edema that ensues following thermal damage ${ }^{38,44,53,54}$ Resorption of the necrotic center continues over the next few months after treatment (for at least 6 months $\mathrm{s}^{38,44}$ ), and during that time the edema decreases and the lesion can decrease to half its original size (Fig. 1).

\section{Commercially Available LITT Systems Used in Neurosurgery}

Two of the most common commercially available LITT systems that have been used in neurosurgery include the NeuroBlate System (Monteris Medical, Inc.) and the Visualase Thermal Therapy System (Medtronic Inc.).

The Visualase system is an integrated, MRI-guided, minimally invasive laser ablation system. It consists of a 15-W, 980-nm diode laser generator that supplies energy to a disposable $1.65-\mathrm{mm}$-diameter outer cooling catheter that contains a 1-cm-long fiberoptic applicator with a light-diffusing tip., ${ }^{9,27}$ The cooling catheter is connected to a peristaltic roller pump that circulates sterile saline to cool the probe tip and surrounding tissues. ${ }^{9}$ The probe allows for thermal delivery in an ellipsoid-cylindrical distribution. The system is connected to a computer workstation that is subsequently connected to an MRI unit, which allows the display of real-time thermographic data at the treatment site. Extracted thermal data produce color-coded "thermal" and "damage" images based on an Arrhenius rate 

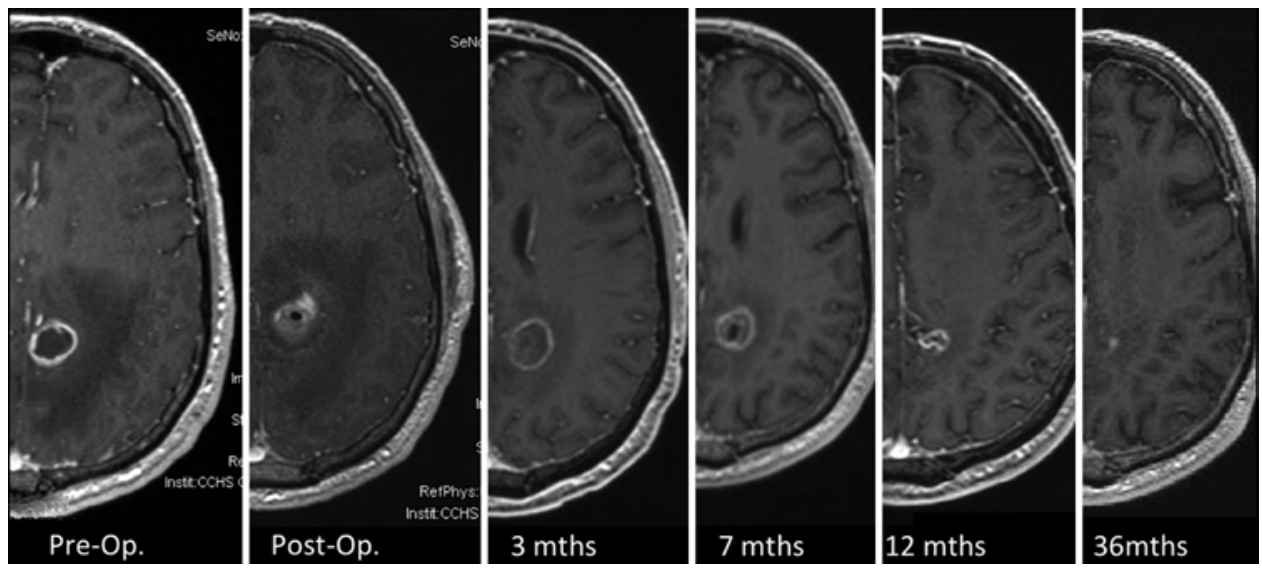

FIG. 1. Postcontrast T1-weighted MR images in a representative case of a left mesial parietal GBM treated using LITT. The 24hour postoperative image demonstrates the central tract of the laser probe, blood products, and decreased tumor enhancement. At 3 months, a peripheral rim of enhancement (eggshell pattern) is seen surrounded by residual edema. Contrast enhancement gradually decreased until 3 years posttreatment.

process model. ${ }^{32,52}$ A feedback control mechanism exists, and temperature limits can be designated as safety points on the pretreatment MR image. If during treatment an increase in temperature above the designated limit is detected at those points, the laser is automatically deactivated.

The NeuroBlate system uses a $\mathrm{CO}_{2}$ gas-cooled laser probe and thermocouple that deliver controlled laser en-

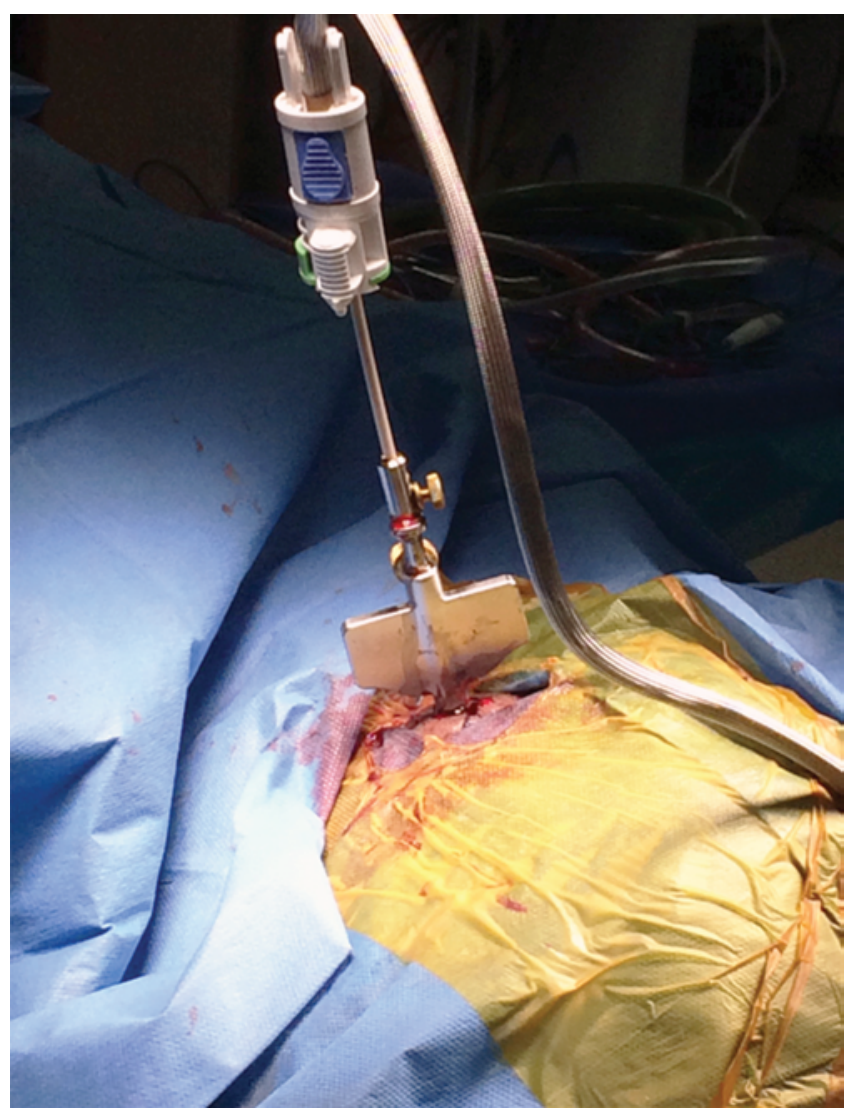

FIG. 2. Intraoperative photograph showing the laser probe placement through a skull bolt. ergy to the intended target. ${ }^{36}$ The system uses an Nd:YAG laser optical fiber, with a laser output of $12 \mathrm{~W}$, and both side-firing and diffuse-tip probes are available. The probes are available with diameters of $3.2 \mathrm{~mm}$ and $2.1 \mathrm{~mm}$ and are inserted using stereotactic guidance using one of several patient-probe interfaces including the AXiiiS device, which serves as a miniature stereotactic guidance frame, aligns to the target, and provides the appropriate trajectory for probe insertion and cranial bolts in addition to some other devices (Fig. 2). The system is connected to a computer workstation that connects to the MRI system, which provides real-time thermographic data. The software displays the extent of thermal energy delivery as thermal-damage-threshold (TDT) lines. A yellow line surrounds the target volume that has been heated to $43^{\circ} \mathrm{C}$ for at least 2 minutes, a blue line surrounds the target volume that has been exposed to $43^{\circ} \mathrm{C}$ for at least 10 minutes, and a white line corresponds to tissue exposed to $43^{\circ} \mathrm{C}$ for 60 minutes. The tissue outside the yellow TDT line is considered to have no permanent damage, the tissue inside the blue line is considered to have severe damage, and the tissue within the white line has undergone coagulation necrosis $^{36}$ (Fig. 3).

\section{Clinical Applications of LITT}

There have been several investigations into potential clinical applications for LITT in neurosurgery. LITT is a minimally invasive alternative to open surgical interventions, harnessing the powers of stereotaxy and thermal ablation. Focally contained, surgically inaccessible lesions are primary targets of this method although it is being more frequently used in cases of surgically accessible lesions as well. LITT can also serve as an alternative in the management of radioresistant tumors or in cases in which the threshold for radiation therapy has been exceeded. Recently, LITT has also been explored as a means for highprecision ablation of focal epileptogenic foci in adults ${ }^{55}$ and children. ${ }^{13}$ Most publications on LITT consist of feasibility and small series, $, 5,7-9,19,27-29,35,39,42,43,45,46,48,52$ and to date, there have been no randomized trials comparing the 


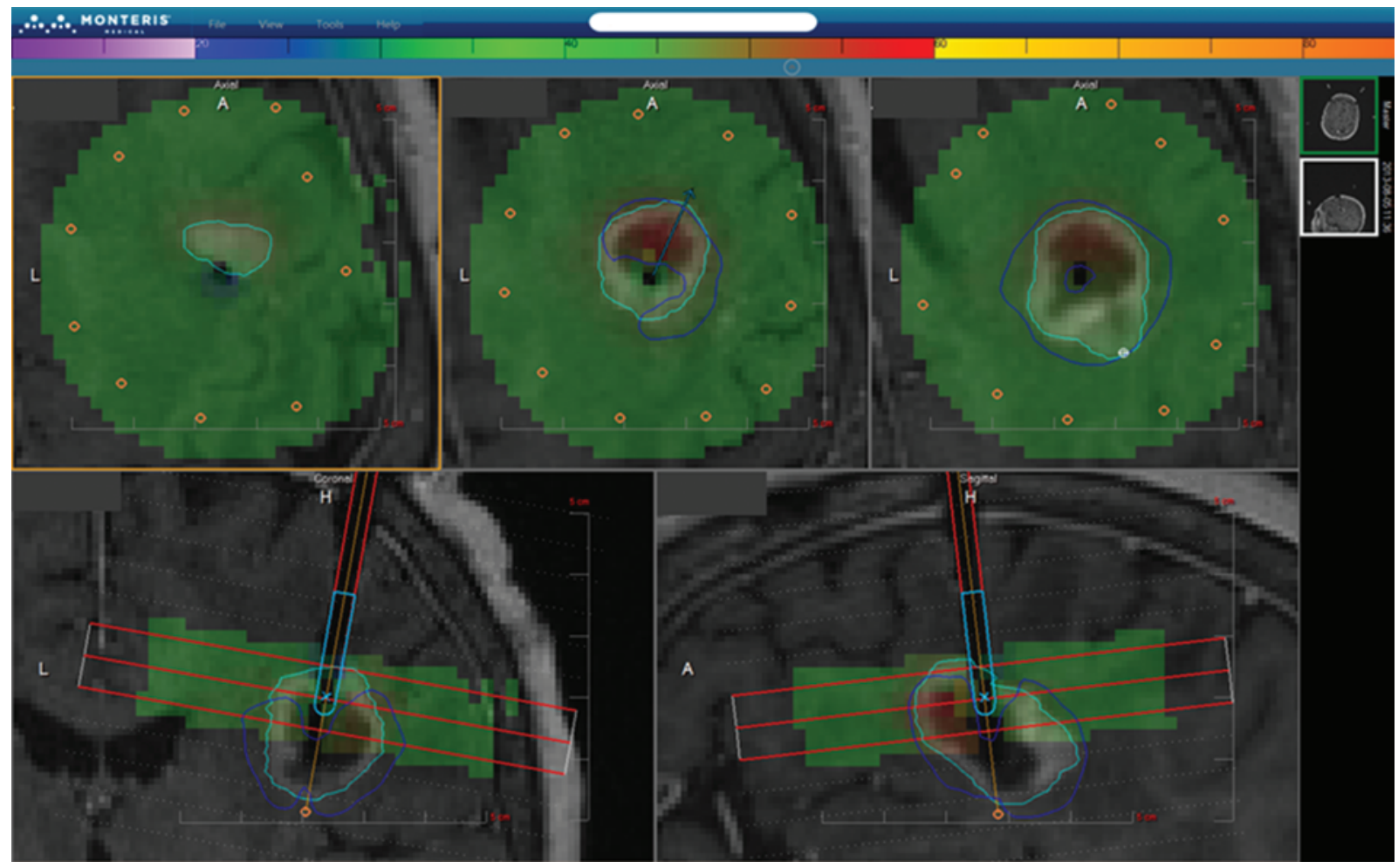

FIG. 3. Screen shot of the M-Vision LITT treatment software, showing the 3 treatment slices that are displayed for treatment and the sagittal and coronal views that demonstrate the cumulative laser thermal treatment. The orange circles are temperature reference points. The tumor contour is displayed in light blue as well as the direction of laser firing for treatment. The deep blue line demonstrates the TDT line that is equivalent to exposure to $43^{\circ} \mathrm{C}$ for at least 10 minutes. The green circle represents the limits of temperature detection via MR thermometry.

effectiveness of this technique with standard treatments (Tables 1-4).

Advantages of LITT over craniotomy include shorter hospital stay, reduced blood loss and postoperative pain, and the ability to perform adjuvant therapies such as chemotherapy or radiation therapy shortly after the procedure given the small incision and reduced healing time. Limitations of LITT include the inability to treat large and irregular lesions or lesions adjacent to major blood vessels or highly vascular lesions. Transient lesion volume increases in the immediate perioperative period may lead to neurological deficits and need for pharmacological or surgical intervention. Lastly, the inability to achieve optimal probe placement in some cases can potentially limit the technique. LITT has been studied in the following clinical applications.

\section{Gliomas}

Numerous authors $2,5,7,24,27-29,33,42,43,45,46,48$ have investigated the use of LITT in the treatment of malignant gliomas. Schwarzmaier and colleagues ${ }^{45}$ reported their results of performing LITT in 16 patients with recurrent glioblastoma multiforme (GBM) using a continuous Nd:YAG laser source. The reported post-LITT median survival was 6.9 months and was better than the historical survival of $<5$ months for recurrent GBM patients at that time. No permanent neurological deficits or deaths related to the procedure were reported in that series. Hawasli and colleagues ${ }^{24}$ also reported on using LITT to treat 11 gliomas (4 recurrent) and 5 brain metastases, assessing the efficacy and safety of the procedure. Jethwa and colleague ${ }^{27}$ described their experience with Visualase system-based LITT for 20 patients with a various lesions including GBM, meningioma, ependymoma, and hemangioblastoma and demonstrated feasibility and safety of the procedure.

The largest series has been reported by Mohammadi and colleagues. ${ }^{35}$ They described the results of a multicenter study of 34 patients who harbored high-grade gliomas (24 glioblastoma and 10 anaplastic lesions) and who underwent NeuroBlate-based LITT as an upfront or salvage therapy. The median progression-free survival (PFS) was 5.1 months and the 1-year overall survival (OS) estimate was $68 \% \pm 9 \%$. Greater tumor coverage by the TDT lines correlated with longer PFS. Missios and colleagues ${ }^{34}$ used the NeuroBlate system to perform LITT in 11 patients with glioblastoma and similarly demonstrated significantly increased PFS and a trend toward increased OS in patients with a wider extent of thermal coverage ( $>98 \%$ blue TDT line coverage or $<0.05 \mathrm{~cm}^{3}$ not covered by the yellow TDT line). Sloan and colleagues ${ }^{46}$ reported the results of the first human study of the NeuroBlate system in a Phase I investigational device exemption-managed study to evaluate dose escalation tolerance and safety of the system in 10 patients with recurrent GBM. Median OS was 10.5 months after LITT and the procedure-related mortality rate was $0 \%$.

Few other small case series and case reports exist de- 
TABLE 1. Studies using LITT to treat primary and recurrent gliomas

\begin{tabular}{|c|c|c|c|c|c|c|}
\hline Authors \& Year & Tumor Type & $\begin{array}{l}\text { No. of } \\
\text { Patients }\end{array}$ & Location of Tumors (no.) & $\begin{array}{l}\text { Range of Lesion } \\
\text { Diameter or Vol }\end{array}$ & $\begin{array}{c}\text { Monitoring } \\
\text { Imaging Modality }\end{array}$ & Complications (no.) \\
\hline $\begin{array}{l}\text { Bettag et al., } \\
1991\end{array}$ & Grade II/III gliomas & 5 & $\begin{array}{l}\text { Frontal (2); thalamic (1); } \\
\text { temporal (2) }\end{array}$ & $1-3.5 \mathrm{~cm}$ & CT, MRI & Local cerebral edema \\
\hline $\begin{array}{l}\text { Sugiyama et al., } \\
1990\end{array}$ & $\begin{array}{l}\text { Gliomas, } \\
\text { metastases }\end{array}$ & 3 & NR & $1-2.5 \mathrm{~cm}$ & CCTS & NR \\
\hline $\begin{array}{l}\text { Ascher et al., } \\
1991\end{array}$ & Grade II gliomas & 8 & NR & NR & NR & NR \\
\hline $\begin{array}{l}\text { Roux et al., } \\
1992\end{array}$ & Grade II gliomas & 4 & $\begin{array}{l}\text { 3rd ventricle (2); basal ganglia } \\
\text { (3) }\end{array}$ & $2.5-3.7 \mathrm{~cm}$ & CCTS & NR \\
\hline $\begin{array}{l}\text { Kahn et al., } \\
1994\end{array}$ & $\begin{array}{l}\text { Grade II/III/IV } \\
\text { gliomas }\end{array}$ & 6 & $\begin{array}{l}\text { Frontal (3); parietal (2); corpus } \\
\quad \text { callosum (1) }\end{array}$ & $1.8-3.4 \mathrm{~cm}$ & MRI & NR \\
\hline $\begin{array}{l}\text { Leonardi et al., } \\
2001\end{array}$ & $\begin{array}{l}\text { Grade II/III/IV } \\
\text { gliomas }\end{array}$ & 24 & $\begin{array}{l}\text { Frontal (7); frontotemporal (2); } \\
\text { frontoparietal (2); temporal } \\
\text { (1); parietal (5); parietooc- } \\
\text { cipital (6); thalamic (1) }\end{array}$ & NR & 0.2-T MRI & $\begin{array}{l}\text { Neurological deficit (4; } \\
2 \text { temporary); super- } \\
\text { ficial wound infection } \\
\text { (2); seizure (1) }\end{array}$ \\
\hline $\begin{array}{l}\text { Schulze et al., } \\
\quad 2004\end{array}$ & Grade III/IV gliomas & 8 & NR & NR & 0.5-T MRI & None \\
\hline $\begin{array}{l}\text { Schwarzmaier } \\
\text { et al., } 2006\end{array}$ & Recurrent GBM & 2 & $\begin{array}{l}\text { Temporal (1); parietooccipital } \\
\text { (1) }\end{array}$ & NR & 0.5-T MRI & NR \\
\hline $\begin{array}{l}\text { Carpentier et } \\
\text { al., } 2012\end{array}$ & Recurrent GBM & 4 & $\begin{array}{l}\text { Temporal (2); corpus callosum } \\
\text { (1); frontal (1) }\end{array}$ & $0.38-8.86 \mathrm{~cm}^{3}$ & 1.5-T MRI & $\begin{array}{l}\text { Neurological deficit (1); } \\
\text { seizures (1) }\end{array}$ \\
\hline $\begin{array}{l}\text { Jethwa et al., } \\
2012\end{array}$ & $\begin{array}{l}\text { Grade III/IV gliomas; } \\
\text { hemangioblas- } \\
\text { toma; chordomas; } \\
\text { metastasis; } \\
\text { ependymomas }\end{array}$ & 20 & $\begin{array}{l}\text { Frontal (6); frontoparietal (2); } \\
\text { temporal (1); parietal (2); } \\
\text { corpus callosum (2); thala- } \\
\text { mus (1); 3rd ventricle (2); } \\
\text { midbrain (1); cerebellum (3) }\end{array}$ & $0.95-9.63 \mathrm{~cm}^{3}$ & 1.5-T MRI & $\begin{array}{l}\text { Vascular injury (1); } \\
\text { cerebral edema/ } \\
\text { hemicraniectomy (1); } \\
\text { inaccurate place- } \\
\text { ment/hemicraniec- } \\
\text { tomy (1); pituitary } \\
\text { injury (1) }\end{array}$ \\
\hline $\begin{array}{l}\text { Sloan et al., } \\
2013\end{array}$ & Recurrent GBM & 10 & $\begin{array}{l}\text { Temporal (2); frontal (3); pari- } \\
\text { etal (3); temporooccipital (1) }\end{array}$ & $2.6-19 \mathrm{~cm}^{3}$ & 1.5-T MRI & $\begin{array}{l}\text { Vascular injury (1); } \\
\text { neurological deficit } \\
\text { (3; } 2 \text { transient) }\end{array}$ \\
\hline $\begin{array}{l}\text { Hawasli et al., } \\
2013\end{array}$ & Grade III/IV gliomas & 11 & $\begin{array}{l}\text { Frontal/parietal (4); insula (1); } \\
\text { thalamus (4); basal ganglia } \\
\text { (1); corpus callosum (1) }\end{array}$ & $2-21.2 \mathrm{~cm}^{3}$ & 1.5-T MRI & $\begin{array}{l}\text { Neurological deficit (5; } \\
\text { all transient); DVT } \\
\text { (1); hyponatremia (1); } \\
\text { fatal meningitis (1) }\end{array}$ \\
\hline $\begin{array}{l}\text { Mohammadi et } \\
\text { al., } 2014^{35}\end{array}$ & Grade III/IV gliomas & 35 & $\begin{array}{l}\text { Frontal (15); temporal (5); } \\
\text { parietal (5); insula (2); } \\
\text { thalamus (7); corpus cal- } \\
\text { losum (1) }\end{array}$ & $0.7-49.9 \mathrm{~cm}^{3}$ & 1.5-T MRI & $\begin{array}{l}\text { Neurological deficit (7; } \\
5 \text { permanent); DVT } \\
\text { (1); hyponatremia (1); } \\
\text { wound infection (2) }\end{array}$ \\
\hline
\end{tabular}

CCTS = computer-controlled temperature system; DVT = deep vein thrombosis; $\mathrm{NR}=$ not reported.

scribing the use of LITT with smaller radiation doses (typically $<6 \mathrm{~W}$ ) and less sophisticated delivery and monitoring systems, sometimes without MR thermography, for a small number of patients $\left(<10\right.$ each). ${ }^{2,5,28,40,48}$ Across the studies in the LITT literature on gliomas, there is significant variability in the monitoring imaging modalities that are used, likely as a result of the long time span over which these studies were completed. Most of the earlier studies were limited to a small number of patients ${ }^{2,48}$ and lacked detailed reports on tumor characteristics, outcomes, and adverse effect reporting. However, the most recent se$\operatorname{ries}^{7,24,27,34,46}$ have followed a significantly improved methodology to investigate the feasibility of this technique.
The lesion location has varied, with most tumors located in deep parts of the brain. A wide range of tumor sizes have been treated. Some studies ${ }^{28,29,42,43,45,48}$ have reported short-term follow-up, demonstrating decreased perilesional edema and tumor size. Longer-term follow-up and the existence of a control population would be useful to establish the efficacy of LITT.

Complications have been reported with the use of LITT, most of which are related to the location of the primary lesion. Complications include wound infection, ${ }^{29}$ neurological deficits, $, 24,27,29,34,46$ vascular injuries, ${ }^{27,46}$ and cerebral edema.5,27 Although pooled results from these studies $^{5,7,24,27,29,34,46}$ should be interpreted with caution, given the 
TABLE 2. Studies using LITT to treat cerebral metastases

\begin{tabular}{|c|c|c|c|c|c|c|}
\hline Authors \& Year & Tumor Type & $\begin{array}{l}\text { No. of } \\
\text { Patients }\end{array}$ & Location of Tumors (no.) & $\begin{array}{l}\text { Range of Lesion } \\
\text { Diameter or Vol }\end{array}$ & $\begin{array}{c}\text { Monitoring } \\
\text { Imaging Modality }\end{array}$ & Complications \\
\hline $\begin{array}{l}\text { Sugiyama et al., } \\
\qquad 1990\end{array}$ & Metastases & 2 & NR & $2.6-5.0 \mathrm{~cm}$ & CCTS & NR \\
\hline Roux et al., 1992 & $\begin{array}{l}\text { Pituitary adenoma; metastatic } \\
\text { melanoma }\end{array}$ & 2 & Pituitary (1); thalamic (1) & $1.5-2.1 \mathrm{~cm}$ & CCTS & NR \\
\hline Kahn et al., 1994 & Lymphoma; adenocarcinoma & 2 & Thalamic (1); parietal (1) & NR & MRI & NR \\
\hline Schulze et al., 2004 & Metastases & 8 & NR & $2-2.8 \mathrm{~cm}$ & 0.5-T MRI & None \\
\hline $\begin{array}{l}\text { Carpentier et al., } \\
2008\end{array}$ & $\begin{array}{l}\text { Metastatic breast \& lung } \\
\text { adenocarcinoma }\end{array}$ & 6 & $\begin{array}{l}\text { Occipital (1); frontal (2); } \\
\text { temporal (1); parietal (2) }\end{array}$ & $0.9-2.5 \mathrm{~cm}$ & 1.5-T MRI & None \\
\hline $\begin{array}{l}\text { Carpentier et al., } \\
2011\end{array}$ & $\begin{array}{l}\text { Metastatic breast \& lung } \\
\text { adenocarcinoma }\end{array}$ & 7 & $\mathrm{NR}$ & $1-3 \mathrm{~cm}$ & 1.5-T MRI & None \\
\hline Hawasli et al., 2013 & $\begin{array}{l}\text { Metastases (colon, fallopian } \\
\text { tube, melanoma, \& NSCLC) }\end{array}$ & 5 & $\begin{array}{l}\text { Insula (1); frontoparietal (1); } \\
\text { parietal (1); frontal (2) }\end{array}$ & $5.2-9.9 \mathrm{~cm}^{3}$ & 1.5-T MRI & None \\
\hline
\end{tabular}

NSCLC = non-small cell lung cancer

widely varied methodologies, the overall rate of complications, which themselves range from mild to severe, was $28.6 \%$ (range $20 \%-50 \%$ per study). Transient or permanent neurological complications were observed in $11.1 \%$ of all patients. ${ }^{5,7,27,29,46} \mathrm{~A}$ potentially severe complication is the vascular injury, which was severe enough to necessitate intervention in $3.2 \%$ of the patients from all studies reporting complications. ${ }^{5,7,27,29,46}$ Refractory cerebral edema, resulting in a hemicraniectomy, was also reported in one study. ${ }^{27}$

\section{Cerebral Metastases}

Deep-seated cerebral metastases resistant to radiation therapy are another potential target for LITT. Most studies on this topic, however, are small, demonstrate great variability, and interpretation of the results is limited given the varied pathology of the metastatic lesions treated. In a Phase I trial, Carpentier and colleagues ${ }^{9}$ investigated the safety and feasibility of Visualase system-based LITT in 4 patients with 6 total metastases and reported similar complications to those observed in the glioma literature. The same author with other coauthors 3 years later reported on a larger series of 7 patients with 15 metastatic tumors and noted no tumor recurrence within the thermal ablation zone and a median OS of 19.8 months. ${ }^{8}$ Hawasli and colleagues ${ }^{24}$ reported on their experience with NeuroBlate LITT in 5 patients with metastatic foci and described shorter PFS and OS durations of 8 and 5.8 months, respectively, after laser treatment.

In general authors have demonstrated an initial transient increase in tumor volume ${ }^{8,9}$ followed by shrinkage of the lesion. Fabiano and $\mathrm{Qiu}^{20}$ published a report on 2 patients with cerebral metastases in whom LITT failed. Both patients initially experienced a response to treatment but the lesions recurred 6 and 11 months after LITT, and examination of the resected tumors demonstrated active tumor without radiation necrosis in both patients. Further investigation is needed to demonstrate the utility of LITT in this patient population.

\section{Radiation Necrosis}

Radiation necrosis is a common late complication of radiation therapy occurring in approximately $5 \%$ of patients and developing several months or as late as $2-3$ years after treatment. ${ }^{21,39}$ The use of LITT for management of this pathology remains restricted to individual case reports and a small patient series. Rahmathulla and colleagues ${ }^{39}$ presented the first report on the use of LITT for medically refractory radiation necrosis, noting resolution of the lesion 7 weeks after treatment and a weaning of the patient from steroids. Similarly, Fabiano and Alberico ${ }^{19}$ reported on a persistently enhancing lesion and refractory cerebral edema treated 14 weeks after radiosurgery, with subsequent improvement of symptoms. Torres-Reveron et al. ${ }^{52}$ reported on 6 patients with radiation necrosis in whom the lesions exhibited a good volumetric response 4.5-6 months after LITT.

\section{Epilepsy}

Surgical interventions for epilepsy have evolved from standard lobectomies to individually tailored approaches

TABLE 3. Studies using LITT to treat radiation necrosis

\begin{tabular}{|c|c|c|c|c|c|c|}
\hline Authors \& Year & Tumor Type & $\begin{array}{l}\text { No. of } \\
\text { Patients }\end{array}$ & Location of Tumors (no.) & Lesion Diameter & $\begin{array}{c}\text { Monitoring } \\
\text { Imaging Modality }\end{array}$ & Complications \\
\hline $\begin{array}{l}\text { Rahmathulla et al., } \\
2012\end{array}$ & $\begin{array}{l}\text { Radiation necrosis after metas- } \\
\text { tasis treatment }\end{array}$ & 1 & Motor cortex & $2 \mathrm{~cm}$ & 1.5-T MRI & None \\
\hline $\begin{array}{l}\text { Torres-Reveron et } \\
\text { al., } 2013\end{array}$ & $\begin{array}{l}\text { Radiation necrosis after metas- } \\
\text { tasis treatment }\end{array}$ & 6 & $\begin{array}{l}\text { Frontal (3); cerebellar (2); } \\
\text { parietooccipital (1) }\end{array}$ & $0.68-3.03 \mathrm{~cm}$ & 1.5-T MRI & NR \\
\hline
\end{tabular}


TABLE 4. Studies using LITT to treat epileptogenic lesions

\begin{tabular}{lclcc}
\hline \multicolumn{1}{c}{ Authors \& Year } & $\begin{array}{c}\text { No. of } \\
\text { Patients }\end{array}$ & \multicolumn{1}{c}{ Location of Lesions (no.) } & $\begin{array}{c}\text { Monitoring Imaging } \\
\text { Modality }\end{array}$ & Complications \\
\hline Curry et al., 2012 & 5 & $\begin{array}{c}\text { Cingulate tuber (1); mesial temporal sclerosis } \\
\text { (1); hypothalamic hamartoma (2); frontal } \\
\text { cortical dysplasia (2) }\end{array}$ & 1.5-T MRI & None \\
\hline Wellmer et al., 2014 & 2 & Frontal (2) & 3-T MRI & Transient mouth paresis (1) \\
\hline Gonzalez-Martinez et al., 2014 & 1 & Frontal (1) & 1.5-T MRI & None \\
\hline Esquenazi et al., 2014 & 2 & Periventricular nodular heterotopia (2) & 3-T MRI & Transient visual deficit (1) \\
\hline
\end{tabular}

and resections,${ }^{55}$ and focal destruction of the epileptogenic focus could potentially have the same outcome as resection. Because LITT is a minimally invasive technique that can deliver high-precision focal thermal ablation, and it has been explored as a new approach to epilepsy surgery. Wellmer and colleagues ${ }^{55}$ reported on the use of stereotactic radiofrequency thermocoagulation for the ablation of focal cortical dysplasia in 2 patients with pharmacoresistant epilepy. Both patients were seizure free at 12 and 5 months, and no deficits were encountered. While the technique does not rely on laser thermal ablation, it shares similarities with LITT, including the stereotactic placement of a probe and thermal ablation. Esquenazi and colleagues ${ }^{18}$ described the safety and feasibility of LITT for the ablation of periventricular nodular heterotopia in 2 patients with pharmacoresistant epilepsy and the authors reported mixed outcomes. Curry and colleagues ${ }^{13}$ reported on 5 pediatric patients who underwent LITT for ablation of focal epileptogenic lesions. No complications were described and all patients were seizure free in a follow-up period of 2-13 months. In a publication of their surgical technique, Gonzalez-Martinez and colleagues $^{23}$ reported on the combined use of a Visualase LITT system with a ROSA robot (Medtech Surgical Inc.) and intraoperative MRI to place LITT probes safely and efficiently for the treatment of an epileptogenic lesion.

\section{Future Directions}

Further development of LITT for neurosurgical applications will rely both on technological advances and refinement of the hardware and software, as well as larger clinical trials, including randomized prospective trials, demonstrating the efficacy of the modality for different pathologies, especially in the glioma population. There are anecdotal reports on the use of LITT to ablate cavernous malformations, as yet unpublished. Improvements in the probe design and technology may allow greater tumor thermal coverage, decreased need for multiple entries, and greater tissue penetration. Selective tumor thermal delivery, with sparing of the normal brain tissue, may be achievable with the use of nanoparticles to induce tissuespecific hyperthermia. Studies have demonstrated a selective uptake by tumor cells of gold nanoshells coated with polyethylene glycol, ${ }^{3,30}$ which can enhance the ablative effect of LITT and improve tissue selectivity.

\section{Conclusions}

LITT has emerged as a promising modality in neuro- surgery for the treatment of lesions that are surgically inaccessible or have failed to be resolved by standard treatment modalities. The initial technical difficulties that limited its initial use have been largely overcome, and several studies have demonstrated the safety profile of this technique. Larger prospective series and standardized indications and protocols are required to demonstrate the efficacy of this technique for these challenging pathologies.

\section{References}

1. Anvari B, Tanenbaum BS, Hoffman W, Said S, Milner TE, Liaw LH, et al: Nd:YAG laser irradiation in conjunction with cryogen spray cooling induces deep and spatially selective photocoagulation in animal models. Phys Med Biol 42:265282, 1997

2. Ascher PW, Justich E, Schröttner O: A new surgical but less invasive treatment of central brain tumours. Preliminary report. Acta Neurochir Suppl (Wien) 52:78-80, 1991

3. Baek SK, Makkouk AR, Krasieva T, Sun CH, Madsen SJ, Hirschberg H: Photothermal treatment of glioma; an in vitro study of macrophage-mediated delivery of gold nanoshells. J Neurooncol 104:439-448, 2011

4. Berns MW, Coffey J, Wile AG: Laser photoradiation therapy of cancer: possible role of hyperthermia. Lasers Surg Med 4:87-92, 1984

5. Bettag M, Ulrich F, Schober R, Fürst G, Langen KJ, Sabel M, et al: Stereotactic laser therapy in cerebral gliomas. Acta Neurochir Suppl (Wien) 52:81-83, 1991

6. Bown SG: Phototherapy in tumors. World J Surg 7:700-709, 1983

7. Carpentier A, Chauvet D, Reina V, Beccaria K, Leclerq D, McNichols RJ, et al: MR-guided laser-induced thermal therapy (LITT) for recurrent glioblastomas. Lasers Surg Med 44:361-368, 2012

8. Carpentier A, McNichols RJ, Stafford RJ, Guichard JP, Reizine D, Delaloge S, et al: Laser thermal therapy: realtime MRI-guided and computer-controlled procedures for metastatic brain tumors. Lasers Surg Med 43:943-950, 2011

9. Carpentier A, McNichols RJ, Stafford RJ, Itzcovitz J, Guichard JP, Reizine D, et al: Real-time magnetic resonance-guided laser thermal therapy for focal metastatic brain tumors. Neurosurgery 63 (1 Suppl 1):ONS21-ONS29, 2008

10. Chen L, Bouley D, Yuh E, D'Arceuil H, Butts K: Study of focused ultrasound tissue damage using MRI and histology. J Magn Reson Imaging 10:146-153, 1999

11. Chen L, Wansapura JP, Heit G, Butts K: Study of laser ablation in the in vivo rabbit brain with MR thermometry. $\mathbf{J}$ Magn Reson Imaging 16:147-152, 2002

12. Cheng MK, McKean J, Boisvert D, Tulip J, Mielke BW: Effects of photoradiation therapy on normal rat brain. Neurosurgery 15:804-810, 1984

13. Curry DJ, Gowda A, McNichols RJ, Wilfong AA: MR-guid- 
ed stereotactic laser ablation of epileptogenic foci in children. Epilepsy Behav 24:408-414, 2012

14. De Poorter J: Noninvasive MRI thermometry with the proton resonance frequency method: study of susceptibility effects. Magn Reson Med 34:359-367, 1995

15. Dougherty TJ, Grindey GB, Fiel R, Weishaupt KR, Boyle DG: Photoradiation therapy. II. Cure of animal tumors with hematoporphyrin and light. J Natl Cancer Inst 55:115-121, 1975

16. Eggert HR, Blazek V: Optical properties of human brain tissue, meninges, and brain tumors in the spectral range of 200 to $900 \mathrm{~nm}$. Neurosurgery 21:459-464, 1987

17. Elias Z, Powers SK, Atstupenas E, Brown JT: Hyperthermia from interstitial laser irradiation in normal rat brain. Lasers Surg Med 7:370-375, 1987

18. Esquenazi Y, Kalamangalam GP, Slater JD, Knowlton RC, Friedman E, Morris SA, et al: Stereotactic laser ablation of epileptogenic periventricular nodular heterotopia. Epilepsy Res 108:547-554, 2014

19. Fabiano AJ, Alberico RA: Laser-interstitial thermal therapy for refractory cerebral edema from post-radiosurgery metastasis. World Neurosurg 81:652.e1-654.e4, 2014

20. Fabiano AJ, Qiu J: Delayed failure of laser-induced interstitial thermotherapy for postradiosurgery brain metastases. World Neurosurg 82:e559-e563, 2014

21. Giglio P, Gilbert MR: Cerebral radiation necrosis. Neurologist 9:180-188, 2003

22. Gomer CJ, Rucker N, Razum NJ, Murphree AL: In vitro and in vivo light dose rate effects related to hematoporphyrin derivative photodynamic therapy. Cancer Res 45:1973-1977, 1985

23. Gonzalez-Martinez J, Vadera S, Mullin J, Enatsu R, Alexopoulos AV, Patwardhan R, et al: Robot-assisted stereotactic laser ablation in medically intractable epilepsy: operative technique. Neurosurgery 10 (Suppl 2):167-173, 2014

24. Hawasli AH, Bagade S, Shimony JS, Miller-Thomas M, Leuthardt EC: Magnetic resonance imaging-guided focused laser interstitial thermal therapy for intracranial lesions: singleinstitution series. Neurosurgery 73:1007-1017, 2013

25. Henderson BW, Waldow SM, Mang TS, Potter WR, Malone PB, Dougherty TJ: Tumor destruction and kinetics of tumor cell death in two experimental mouse tumors following photodynamic therapy. Cancer Res 45:572-576, 1985

26. Higuchi N, Bleier AR, Jolesz FA, Colucci VM, Morris JH: Magnetic resonance imaging of the acute effects of interstitial neodymium:YAG laser irradiation on tissues. Invest Radiol 27:814-821, 1992

27. Jethwa PR, Barrese JC, Gowda A, Shetty A, Danish SF: Magnetic resonance thermometry-guided laser-induced thermal therapy for intracranial neoplasms: initial experience. Neurosurgery 71 (1 Suppl Operative):133-144, 144-145, 2012

28. Kahn T, Bettag M, Ulrich F, Schwarzmaier HJ, Schober R, Fürst G, et al: MRI-guided laser-induced interstitial thermotherapy of cerebral neoplasms. J Comput Assist Tomogr 18:519-532, 1994

29. Leonardi MA, Lumenta CB, Gumprecht HK, von Einsiedel $\mathrm{GH}$, Wilhelm T: Stereotactic guided laser-induced interstitial thermotherapy (SLITT) in gliomas with intraoperative morphologic monitoring in an open MR-unit. Minim Invasive Neurosurg 44:37-42, 2001

30. Madsen SJ, Baek SK, Makkouk AR, Krasieva T, Hirschberg H: Macrophages as cell-based delivery systems for nanoshells in photothermal therapy. Ann Biomed Eng 40:507-515, 2012

31. Marchesini R, Andreola S, Emanuelli H, Melloni E, Schiroli A, Spinelli P, et al: Temperature rise in biological tissue during Nd:YAG laser irradiation. Lasers Surg Med 5:75-82, 1985

32. McNichols RJ, Gowda A, Kangasniemi M, Bankson JA,
Price RE, Hazle JD: MR thermometry-based feedback control of laser interstitial thermal therapy at $980 \mathrm{~nm}$. Lasers Surg Med 34:48-55, 2004

33. Mensel B, Weigel C, Hosten N: Laser-induced thermotherapy. Recent Results Cancer Res 167:69-75, 2006

34. Missios S, Schroeder JL, Barnett GH, Mohammadi AM: Prognostic factors of overall survival after laser interstitial thermal therapy in patients with glioblastoma. Photonics Lasers Med 3:143-150, 2014

35. Mohammadi AM, Hawasli AH, Rodriguez A, Schroeder JL, Laxton AW, Elson P, et al: The role of laser interstitial thermal therapy in enhancing progression-free survival of difficult-to-access high-grade gliomas: a multicenter study. Cancer Med 3:971-979, 2014

36. Mohammadi AM, Schroeder JL: Laser interstitial thermal therapy in treatment of brain tumors - the NeuroBlate System. Expert Rev Med Devices 11:109-119, 2014

37. Norred SE, Johnson JA: Magnetic resonance-guided laser induced thermal therapy for glioblastoma multiforme: a review. Biomed Res Int 2014:761312, 2014

38. Rahmathulla G, Recinos PF, Kamian K, Mohammadi AM, Ahluwalia MS, Barnett GH: MRI-guided laser interstitial thermal therapy in neuro-oncology: a review of its current clinical applications. Oncology 87:67-82, 2014

39. Rahmathulla G, Recinos PF, Valerio JE, Chao S, Barnett GH: Laser interstitial thermal therapy for focal cerebral radiation necrosis: a case report and literature review. Stereotact Funct Neurosurg 90:192-200, 2012

40. Reimer P, Bremer C, Horch C, Morgenroth C, Allkemper T, Schuierer G: MR-monitored LITT as a palliative concept in patients with high grade gliomas: preliminary clinical experience. J Magn Reson Imaging 8:240-244, 1998

41. Rieke V, Butts Pauly K: MR thermometry. J Magn Reson Imaging 27:376-390, 2008

42. Roux FX, Merienne L, Fallet-Bianco C, Beuvon F, Devaux B, Leriche B, et al: [Stereotaxic laser interstitial thermotherapy. A new alternative in the therapeutic management of some brain tumors.] Neurochirurgie 38:238-244, 1992 (Fr)

43. Schulze PC, Vitzthum HE, Goldammer A, Schneider JP, Schober R: Laser-induced thermotherapy of neoplastic lesions in the brain-underlying tissue alterations, MRI-monitoring and clinical applicability. Acta Neurochir (Wien) 146:803-812, 2004

44. Schwabe B, Kahn T, Harth T, Ulrich F, Schwarzmaier HJ: Laser-induced thermal lesions in the human brain: short- and long-term appearance on MRI. J Comput Assist Tomogr 21:818-825, 1997

45. Schwarzmaier HJ, Eickmeyer F, von Tempelhoff W, Fiedler VU, Niehoff H, Ulrich SD, et al: MR-guided laser-induced interstitial thermotherapy of recurrent glioblastoma multiforme: preliminary results in 16 patients. Eur J Radiol 59:208-215, 2006

46. Sloan AE, Ahluwalia MS, Valerio-Pascua J, Manjila S, Torchia MG, Jones SE, et al: Results of the NeuroBlate System first-in-humans Phase I clinical trial for recurrent glioblastoma. Clinical article. J Neurosurg 118:1202-1219, 2013

47. Stafford RJ, Fuentes D, Elliott AA, Weinberg JS, Ahrar K: Laser-induced thermal therapy for tumor ablation. Crit Rev Biomed Eng 38:79-100, 2010

48. Sugiyama K, Sakai T, Fujishima I, Ryu H, Uemura K, Yokoyama T: Stereotactic interstitial laser-hyperthermia using Nd-YAG laser. Stereotact Funct Neurosurg 54-55:501-505, 1990

49. Svaasand LO: Photodynamic and photohyperthermic response of malignant tumors. Med Phys 12:455-461, 1985

50. Svaasand LO, Ellingsen R: Optical penetration in human intracranial tumors. Photochem Photobiol 41:73-76, 1985

51. Svaasand LO, Ellingsen R: Optical properties of human brain. Photochem Photobiol 38:293-299, 1983 
52. Torres-Reveron J, Tomasiewicz HC, Shetty A, Amankulor NM, Chiang VL: Stereotactic laser induced thermotherapy (LITT): a novel treatment for brain lesions regrowing after radiosurgery. J Neurooncol 113:495-503, 2013

53. Tracz RA, Wyman DR, Little PB, Towner RA, Stewart WA, Schatz SW, et al: Comparison of magnetic resonance images and the histopathological findings of lesions induced by interstitial laser photocoagulation in the brain. Lasers Surg Med 13:45-54, 1993

54. Tracz RA, Wyman DR, Little PB, Towner RA, Stewart WA, Schatz SW, et al: Magnetic resonance imaging of interstitial laser photocoagulation in brain. Lasers Surg Med 12:165173,1992

55. Wellmer J, Kopitzki K, Voges J: Lesion focused stereotactic thermo-coagulation of focal cortical dysplasia IIB: a new approach to epilepsy surgery? Seizure 23:475-478, 2014

56. Yaroslavsky AN, Schulze PC, Yaroslavsky IV, Schober R,
Ulrich F, Schwarzmaier HJ: Optical properties of selected native and coagulated human brain tissues in vitro in the visible and near infrared spectral range. Phys Med Biol 47:2059-2073, 2002

\section{Author Contributions}

Conception and design: Missios, Barnett. Acquisition of data: Missios, Barnett. Analysis and interpretation of data: Missios, Barnett. Drafting the article: all authors. Critically revising the article: all authors. Reviewed submitted version of manuscript: Missios, Barnett. Study supervision: Barnett.

\section{Correspondence}

Symeon Missios, Department of Neurosurgery, LSU Health Sciences Shreveport, 1501 Kings Hwy., Shreveport, LA 71105. email:smissios@gmail.com. 